\title{
Retraction Note: Coastline climate environment and community public service development model based on GIS
}

\author{
Guibin Xiong $^{1}$
}

Published online: 22 November 2021

C) Saudi Society for Geosciences 2021

Retraction Note: Arabian Journal of Geosciences (2021) 14: 1705 https://doi.org/10.1007/s12517-021-07888-5

The Editor-in-Chief and the Publisher have retracted this article because the content of this article is nonsensical. The peer review process was not carried out in accordance with the Publisher's peer review policy. The author disagrees with this retraction.

The original article can be found online at https://doi.org/10.1007/ s12517-021-07888-5.

Guibin Xiong

wsxgb8@163.com

1 Sociology School, China University of Political Science and Law, Changping, Beijing 102249, China 